1768 by Jonathan Carver, who, like Dr. Morse, was a native of Connecticut. Carver, of whom little is known, was, during his western travels, on the Yellow River in the northeast corner of Iowa in the fall of 1766. Although his book is considered of comparatively little worth by historical authorities today, it enjoyed a great vogue at the time of Dr. Morse's writing activities. Undoubtedly The American Gazetteer drew some of its materials about the country west of the Mississippi, including Iowa, from this work; and it is possible that Dr. Morse secured some of his sparse information on Iowa in particular from intimates of Carver in Boston, or from materials which he may have left there.

\title{
KOSSUTH VISITS SAINT LOUIS
}

The Bon Accord, Captain J. L. Bissel, arrived Sunday evening at 10 o'clock, being the second boat of the season. We are under obligations to the clerk for papers of the 10th inst. Kossuth was in St. Louis, having arrived there on the 7 th at 2 P. M., from Louisville in the Emperor, Captain Hopkins, who has tendered to Kossuth and suite a free passage, which was accepted. Kossuth intends to leave St. Jouis today or tomorrow, and goes to New Orleans, stopping at Vicksburg and Natches. $\mathrm{He}$ was received at $\mathrm{St}$. Louis by Mayor Kennett in a short speech, to which he made a corresponding grateful reply. The Kossuth committee made no definite arrangements known to the public beyond the first day. The Intelligencer says that Kossuth informed the committee that he did not come there for the purpose of being feasted or to meet with any imposing manifestations of admiration or regard. He had come solely for the purpose of obtaining material aid, and unless he found a likelihood of succeeding in that object, his stay would be very short. $\mathrm{He}$ also intimated that before taking any steps himself he would prefer to have a public and more definite welcoming reception than that which had already transpired, in order that he might know how better to shape his course in St. Louis.-Western Democrat, Bellevue, Iowa, March 17, 1852. (In the Newspaper Division of the Historical, Memorial and Art Department of Iowa.) 
Copyright of Annals of Iowa is the property of State of Iowa, by \& through the State Historical Society of Iowa and its content may not be copied or emailed to multiple sites or posted to a listserv without the copyright holder's express written permission. However, users may print, download, or email articles for individual use. 